\title{
PEMBINAAN WARGA BINAAN PEMASYARAKATAN YANG MENJALANI PEMBEBASAN BERSYARAT DIKAITKAN DENGAN UNDANG-UNDANG PEMASYARAKATAN
}

\author{
Henny Saida Flora \\ Fakultas Hukum Universitas Katolik Santo Thomas Medan, Indonesia \\ Email: hennysaida@yahoo.com
}

\begin{abstract}
ABSTRAK
Pembebasan Bersyarat merupakan salah satu bentuk pembinaan untuk warga binaan Pemasyarakatan yang telah menjalani dua pertiga dari masa pidana yang telah dijalankan. Maksud dari pembebasan bersyarat adalah sebagai salah satu upaya untuk memulihkan hubungan warga binaan pemasyarakatan dengan masyarakat dan memperoleh serta meningkatkan peran serta masyarakat secara aktif dalam menyelenggarakan pemasyarakatan. Adanya model pembinaan bagi warga binaan pemasyarakatan di dalam Lembaga Pemasyarakatan tidak terlepas dari sebuah dinamika yang bertujuan untuk lebih banyak memberikan bekal bagi warga binaan pemasyarakatan yang menyongsong kehidupan setelah selesai menjalani masa hukuman (bebas). Pemasyarakatan dinyatakan sebagai suatu sistem pembinaan terhadap para pelanggar hukum keadilan yang bertujuan untuk mencapai reintegrasi sosial atau pulihnya kesatuan hubungan antara warga binaan pemasyarakatan dengan masyarakat selanjutnya pembinaan warga binaan pemasyarakatan diharapkan agar warga binaan pemasyarakatan mampu memperbaiki diri dan tidak mengulangi tindak pidana yang pernah dilakukannya.
\end{abstract}

\section{Kata Kunci: Pembinaan, Warga Binaan Pemasyarakatan, Pembebasan Bersyarat}

\section{ABSTRACT}

Parole is a form of coaching for prisoners who have served two-thirds of the criminal period that has been carried out. The purpose of parole is as an effort to restore the relationship between prisoners and the community and to obtain and increase active community participation in holding prisons. The existence of a coaching model for correctional inmates in the Correctional Institution cannot be separated from a dynamic that aims to provide more provisions for correctional inmates who are facing life after completing their sentence (free). Correctional is stated as a coaching system for violators of the law of justice which aims to achieve social reintegration or the restoration of the unity of the relationship between the prisoners and the community.

\section{Keywords: Guidance, Correctional Inmates, parole}

\section{A. PENDAHULUAN}

Sistem pemasyarakatan adalah suatu tatanan mengenai arah dan batas serta cara pembinaan warga binaan masyarakat berdasarkan pancasila yang dilaksanakan secara terpadu antara Pembina, yang dibina, dan masyarakat untuk meningkatkan kualitas warga binaan pemasyarakatan agar menyadari kesalahan, memperbaiki diri dan tidak mengulangi tindak pidana sehingga dapat diterima kembali oleh lingkungan masyarakat dapat aktif berperan dalam pembangunan dan dapat hidup secara wajar sebagai warga negara yang baik dan bertanggung jawab . 
Sistem pembinaan narapidana dnegan nama pemasyarakatan mulai dikenal pada Tahun 1964 ketika dalam Konferensi Dinas Kepenjaraan di Lembang, tanggal 27 April 1964, Sahardjo melontarkan gagasan perubahan tujuan pembinaan narapidana dari sistem kepenjaraan ke sistem pemasyarakatan. Sebelumnya Sahardjo telah terlebih dahulu mengemukakan gagasan perubahan tujuan pembinaan narapidana itu, dalam pidato pengukuhannya sebagai Doktor Honoris Causa di Istana Negara pada tanggal 15 Juli 1963. Menurut Sahardjo untuk memperlakukan narapidana diperlukan landasan sistem pemasyarakatan. ${ }^{1}$ Bahwa tidak saja masyarakat diayomi terhadap diulangi perbuatan jahat oleh terpidana melainkan juga orang yang telah tersesat diayomi dengan memberikan kepadanya bekal hidup sebagai warga yang berguna di dalam masyarakat. Dari pengayom itu nyata bahwa menjatuhkan pidana bukanlah tindakan balas dendam dari negara. Tobat tidak dapat dicapai dengan penyiksaan melainkan dengan bimbingan. Terpidana juga tidak dijatuhi pidana siksaan melainkan pidana hilang kehilangan kemerdekaan. Negara telah mengambil kemerdekaan seseorang dan yang pada awalnya akan mengembalikan orang itu ke masyarakat lagi, mempunyai kewajiban terhadap orang terpidana itu dan masyarakat. ${ }^{2}$

Gagasan Sahardjo kemudian dirumuskan dalam Konferensi Dinas Kepenjaraan di Lembang Bandung dalam sepuluh prinsip pembinaan narapidana dan bimbingan bagi narapidana. Prinsip-prinsip untuk bimbingan dan pembinaan adalah:

1. Orang yang tersesat harus diayomi dengan memberikan kepadanya bekal hidup sebagai warga negara yang baik dan berguna dalam masyarakat

2. Penjatuhan pidana bukan tindakan pembalasan dendam dari negara

3. Rasa tobat tidak dapatlah dicapai dengan menyiksa melainkan dengan bimbingan

4. Negara tidak berhak membuat seseorang narapidana lebih buruk atau lebih jahat daripada sebelum ia masuk lembaga

5. Selama kehilangan kemerdekaan bergerak narapidana berhak dikenalkan kepada masyarakat dan tidak boleh diasingkan dari masyarakat.

6. Pekerjaan yang diberikan kepada narapidana tidak boleh bersifat mengisi waktu atau hanya diperuntukkan bagi kepentingan lembaga atau negara saja. Pekerjaan yang diberikan harus ditujukan harus ditujukan untuk pembangunan negara

7. Bimbingan dan didikan harus berdasarkan asas pancasila

8. Tiap orang adalah manusia dan harus diperlakukan sebagai manusia meskipun ia telah tersesat. Tidak boleh ditunjukkan kepada narapidana bahwa ia itu penjahatn

9. Narapidana itu hanya dijatuhi pidana hilang kemerdekaan

10. Sarana fisik lembaga dewasa ini merupaakan salah satu hambatan pelaksanaan sistem pemasyarakatan. ${ }^{3}$

Kesepuluh prinsip-prinsip bimbingan dan pembinaan narapidana lebih dikenal sebagai sepuluh pemasyarakatan. Prinsip pemasyarakatan mengajarkan bahwa narapidana adalah orang tersesat sebab itu harus diayomi dan diberikan bekal hidup sebagai warga yang baik dan berguna dalam masyarakat. Pembinaan narapidana adalah upaya untuk mempersiapkan

\footnotetext{
${ }^{1}$ Menurut Pasal 1 ayat 1 UU Nomor 12 Tahun 1995, Sistem Pemasyarakatan, adalah suatu tatanan mengenai arah dan batas serta cara pembinaan warga binaan pemasyarakatan berdasarkan pancasila yang dilaksanakan secara terpadu antara Pembina, yang dibina dan masyarakat untuk meningkatkan kualitas warga binaan pemasyarakatan agar menyadari kesalahannya, memperbaiki diri dan tidak mengulangi tindak pidana sehingga dapat diterima kembali oleh lingkungan masyarakat, dapat aktif berperan dalam pembangunan dan dapat hidup secara wajar sebagai warga negara yang baik dan bertanggung jawab, Marlina, 2012, Hukum Penitensier, Refika Aditama, Bandung, hlm. 125.

${ }^{2}$ Sahardjo, Pohon Beringin Pengayom Hukum Pancasila, Pidato Pengukuhan pada tanggal 3 Juli 1963, di Istana Negara, Universitas Indonesia, hlm. 8

${ }^{3}$ Dwidja Priyatno, 2006, Sistem Pelaksanaan PIdana Penjara di Indonesia, Refika Aditama, Bandung, hlm.9899
} 
narapidana kembali ke masyarakat jadi tidak selayaknya dalam pemasyarakatan masih ada kemungkinan seorang narapidana tidak dapat kembali ke masyarakat. sebagaimana tercantum dalam prinsip kelima dari prinsip-prinsip pemasyarakatan bahwa selama kehilangan kemerdekaan bergerak narapidana harus dikenalkan kepada masyarakat dan tidak boleh diasingkan dari masyarakat agar narapidana tidak canggung saat kembali ke masyarakat.

Menurut Petrus Irwan dan Pandapotan Simorangkir, narapidana adalah orang yang tersesabt yang mempunyai waktu dan kesempata untuk bertobat. ${ }^{4}$ Tobat tidak dapat dicapai dengan penyiksaan melainkan dengan bimbingan. Memahami hal ini jelas bahwa pembinaan narapidana tidak dilakukan dengan kekerasan melainkan dengan cara-cara manusiawi yang menghargai hak-hak narapidana.

Dalam hal ini seorang narapidana yang sedang menjalani masa pidana yang telah dijatuhkan berdasarkan perbuatan pidana yang telah dilakukannya, bisa bebas sebelum masa pidana yang telah dijatuhkan tersebut berakhir. Pembebasan tersebut dapat diberikan apabila seorang narapidana dalam menjalani pidana tersebut menunjukkan sikap baik dan menjalani pembinaan yang diberikan di dalam maupun di luar lembaga pemasyarakatan. Pembebasan yang diberikan tersebut dapat berupa pemberian remisi, pemberian cuti menngunjungi keluarga, pemberian cuti menjelang bebas dan lain sebagainya sesuai yang diatur dalam Pasal 14 UU Pemasyarakatan tentang hak-hak narapidana. Oleh karena itu diadakanlah pembebasan bersyarat sebagai salah satu bagian dari pembinaan narapidana. Menurut Penjelasan Pasal 14 UU Pemasyarakatan, pembebasan bersyarat adalah bebasnya narapidana setelah menjalani sekurang-kurangnya dua pertiga masa pidananya dengan ketentuan dua pertiga tersebut tidak kurang dari sembilan bulan. Pembebasan bersyarat diberikan kepada narapidana agar narapidana dapat langsung menyesuaikan dirinya dengan kehidupan masyarakat sebelum mengakhiri masa pidananya.

Narapidana yang berada di lembaga pemasyarakatan dan sudah menjalani masa pidananya selama dua pertiga dari masa pidananya atau sekurang-kurangnya sembilan bulan maka Tim Pengamat Pemasyarakatan mengadakan sidang. Apabila dalam pengamatan dan penilaian Tim Pengamat Pemasyarakatan narapidana tersebut memenuhi persyaratan dan memungkinkan untuk memasuki tahap akhir menjalani pidananya maka narapidana tersebut diusulkan mendapat pembebasan bersyarat. Proses yang ditempuh pertama kali kepala Lembaga Pemasyarakatan meminta kepada pihak Bapas untuk mengadakan penelitian kemasyarakatan terhadap narapidana dimaksud di wilayah lingkungan dimana terpidana akan menjalani integrasinya. Hal ini untuk mengetahui apakah lingkungan tersebut memungkinkan atau mendukung untuk pelaksanaan integrasi atau pembebasan bersyarat. Oleh karena itu sangatlah penting apabila terhadap narapidana yang menjalani pembebasan bersyarat diberikan bimbingan, dalam rangka membentuk narapidana tersebut agar menjadi manusia seutuhnya, menyadari kesalahannya, memperbaiki diri dan tidak mengulangi tindak pidana sehingga dapat diterima kembali oleh lingkungan masyarakat, dapat aktif berperan dalam pembangunan dan dapat hidup secara wajar sebagai warga yang baik dan bertanggung jawab.

\section{B. PEMBAHASAN}

\section{Pengertian Warga Binaan Pemasyarakatan}

Dalam Pasal 1 ayat (5) UU Pemasyarakatan Warga Binaan Pemasyarakatan adalah Narapidana, Anak didik Pemasyarakatan dan Klien Pemasyarakatan. Selanjutnya dalam ayat (7) menegaskan narapidana adalah terpidana yang menjalani pidana hilang kemerdekaan di Lapas. Sedangkan dalam ayat (8) menegaskan anak didik pemasyarakatan adalah:

\footnotetext{
${ }^{4}$ Petrus Irwan Panjaitan, dan Pandapotan Simorangkir, 2005, Lembaga Pemasyarakatan dalam Perspektif Sistem Peradilan Pidana, Pustaka Sinar Harapan, Jakarta, hlm. 72.
} 
a. Anak pidana yaitu anak yang berdasarkan putusan pengadilan menjalani pidana di Lapas anak paling lama sampai berumur 18 tahun (delapan belas tahun)

b. Anak negara yaitu anak yang berdasarkan putusan pengadilan diserahkan pada negara untuk dididik dan ditempatkan di Lapas Anak paling lama sampia berumu 18 (delapan belas) tahun

c. Anak sipil yaitu anak yang atas permintaan orang tuan atau walinya memperoleh penetapan pengadilan untuk dididik di Lapas anak paling lama sampai berumur 18 (delapan belas) tahun.

Sedangkan yang dimaksud dengan Klien Pemasyarakatan dalam ayat (9) menegaskan Klien adalah seseorang yang berada dalam bimbingan Bapas.

Warga Binaan Pemasyarakatan yang merupakan narapidana bukan saja objek melainkan juga sebagai subjek yang tidak berbeda dengan manusia lainnya yang sewaktuwaktu dapat melakukan kesalahan atau kekhilafan yang dapat dikenakan pidana, sehingga tidak harus diberantas. Hal yang harus diberantas adalah faktor-faktor yang dapat menyebabkan narapidana berbuat hal-hal yang bertentangan dengan hukum, kesusilaan, agama atau kewajiban-kewajiban sosial yang dapat dikenakan pidana.

Dalam Pasal 1 butir 32 KUHAP tidak menyebutkan narapidana melainkan terpidana yang artinya seorang yang dapat dipidana berdasarkan putusan pengadilan yang telah berkekuatan hukum tetap. Hal ini berbeda dengan ruusan dalam kamus hukum pidana yang menyebutkan bahwa narapidana adalah orang yang menjalani pidana dalam lembaga pemasyarakatan, hal ini erat kaitannya dengan Pasal 272, 280,281 dan 282 KUHAP. ${ }^{5}$

Berdasarkan rumusan Pasal 1 butir 7 UU Pemasyarakatan, narapidana adalah terpidana yang menjalani pidana hilang kemerdekaan di lembaga pemasyarakatan. Terpidana itu sendiri yagn dimuat dalam Pasal 1 butir 6 UU Pemasyarakatan adalah seorang yang dipidana berdasarkan putusan pengadilan yang telah memperoleh kekuatan hukum tetap.

Sebagai ciptaan Tuhan, seseorang walaupun telah menjalani terpidana hak-hak yang melekat pada dirinya tetap harus dihargai. Hal itu diakui serta dilindungi oleh kekuatan hukum yang berlaku yang berdasar pada Pancasila dan UUD 1945. Hak-hak narapidana di dalam UU Pemasyarakatan telah ditentukan bahwa setiap orang mempunyai hak-hak yang sah, dan petugas pemasyarakatan wajib menghormati dan mengawasi serta menjunjung tinggi hak-hak narapidana tersebut.

Hak-hak narapidana tersebut telah dirumuskan di dalam pasal 14 ayat 1 UU Pemasyarakatan yaitu:

a. Melakukan ibadah sesuai dengan agama dan kepercayaannya

b. Mendapat perawatan, baik perawatan rohani maupun jasmani

c. Mendapat pendidikan dan pengajaran

d. Mendapat pelayanan kesehatan dan makanan yang layak

e. Menyampaikan keluhan

f. Mendapat bahan bacaan dan mengikuti siaran media massa lainnya yang tidak dilarang

g. Mendapat upah atau premi atas pekerjaan yang dilakukan

h. Menerima kunjungan keluarga, penasehat hukum, atau orang tertentu lainnya

i. Mendapat pengurangan masa pidana (remisi)

j. Mendapat kesempatan berasimilasi termasuk cuti mengunjungi keluarga

k. Mendapat pembebasan bersyarat

1. Mendapat cuti menjelang bebas dan mendapat hak-hak lain sesuai peraturan perundangundangan yang berlaku.

${ }^{5}$ Sudarsono, 1999, Kamus Hukum, Cetakan II, Rineka Cipta, Jakarta, hlm.283. 
Selanjutnya disebutkan dalam Pasal 14 ayat 2 UU Pemasyarakatan bahwa ketentuan mengenai syarat-syarat dan tata cara pelaksanaan hak-hak narapidana sebagaimana dimasksud dalam ayat (1) diatur lebih lanjut dengan Peraturan Pemerintah. Hal ini berarti akan ada pengecualian terhadap narapidana yang tidak memenuhi syarat-syarat untuk mendapat haknya.

Dalam PP Nomor 32 Tahun 1999 jo PP Nomor 28 Tahun 2006 tentang Syarat dan Tata Cara Pelaksanaan Hak Warga Binaan Pemasyarakatan ditentukan bahwa hak-hak narapidana adalah:

1. Setiap narapidana dan anak didik pemasyarakatan berhak untuk melakukan Ibadan sesuai dengan agama dan kepercayaannya (Pasal 2 ayat 1).

2. Setiap narapidana dan anak didik pemasyarakatan berhak mendapat perawatan rohani dan jasmani (Pasal 5)

3. Setiap narapidana dan anak didik pemasyarakatan berhak mendapat perawatan jasmani berupa:

a. Pemberian kesempatan melakukan olah raga dan rekreasi

b. Pemberian perlengkapan pakaian

c. Pemberian perlengkapan tidur dan mandi (Pasal 7 ayat 1).

4. Setiap narapidana dan anak didik pemsyarakatan berhak memperoleh pelayanan kesehatan yang layak (Pasal 14 ayat1)

5. Setiap narapidana dan anak didik pemasyarakatan berhak mendapatkan makanan dan meinuman sesuai dengan jumlah kalori yang memenuhi syarat kesehatan (Pasal 19)

6. Setiap narapidana dan anak didik pemasyarakatan yang sakit, hamil, atau menyusui, berhak mendapatkan makanan tambahan sesuai dengan petunjuk dokter (Pasal 20 ayat 1)

7. Setiap narapidana dan anak didik pemasyarakatan berhak menyampaikan keluhan kepada kepala lembaga pemasyarakatan atau perlakuan petugas atau sesama penghuni terhadap dirinya (Pasal 26 ayat 1 )

8. Setiap narapidana berhak mendapatkan upah atau premi (Pasal 29)

9. Setiap narapidana dan anak pidana yan selama menjalani masa pidana berkelakuan baik berhak mendapatkan remisi (Pasal 34ayat 1)

10. Setiap narapidana dan anak didik pemasyarakatan berhak mendapatkan asimilasi (Pasal 36)

11. Setiap narapidana dan anak didik pemasyarakatan kecuali anak sipil, berhak mendapatkan pembebasan bersyarat (Pasal 43 ayat 1)

12. Hak politik bagi narapidana dan anak didik pemasyarakatan adalah hak menjadi anggota partai politik sesui dengan aspirasinya (Pasal 52 ayat 2).

13. Narapida dan anak didik pemasyarakatan diberikan kesempatan untuk menggunakan hak pilihnya dalam pemilihan umum sesuai dengan peraturan perundang-undangan yang berlaku (Pasal 51 ayat 3).

14. Hak keperdataan lainnya dalam peraturan pemerintah ini meliputi

a. Surat menyurat dengan keluarga dan sahabat-sahabatnya

b. Izin keluar lembaga pemasyarakatan dalam hal-hal luar biasa (Pasal 52).

Menurut PAF Lamintang hak-hak narapidana telah ditentukan dalam manual kemasyarakatan yaitu setiap narapidana mempunyai hak-hak tertentu yang sah menurut peraturan yang berlaku. ${ }^{6}$ Lebih lanjut diketahui bahwa setiap petugas lembaga pemasyarakatan wajib menghormati dan menjunjung tinggi hak-hak dari narapidana tersebut.

${ }^{6}$ P.A.F. Lamintang, 1998, Hukum Penitensier Indonesia, Cetakan Ketiga, Armico, Bandung, hlm. 196, 
Sepanjang tidak ditentukan lain, pemberian hak bagi narapidana itu harus dilaksanakan pada waktunya setelah memenuhi persyaratan-persyaratan yang telah ditetapkan. Usaha untuk memperlambat pelaksanaan pemberian hak-hak tersebut tanpa alasan yang dibenarkan menurut peraturan yang berlaku merupakan pelanggaran disiplin.

Sepanjang tidak ditentukan lain, setiap narapidana itu selama menjalankan pidana mereka berhak untuk:
a. Mengadakan hubungan secara terbatas
b. Memperoleh remisi
c. Memperoleh cuti
d. Memperoleh asimilasi
e. Memperoleh lepas bersyarat ${ }^{7}$

Hak-hak narapidana tersebut diterapkan dalam sistem pemasyarakatan. Untuk melaksanakan sistem pemasyarakatan tersebut diperlukan juga keikutsertaan masyarakat, baik dengan mengadakan kerjasama dalam pembinaan maupun dengan sikap bersedia dengan menerima kembali warga binaan pemasyarakatan yang telah selesai menjalani pidananya. Selanjutnya untuk menjamin terselenggaranya hak-hak tersebut selain diadakan Unit Pelaksana Teknis Pemasyarakatan yang secara langsung melaksanakan pembinaan, diadakan pula Balai Pertimbagnan Pemasyarakatan yang memberi saran dan pertimbangan kepada menteri mengenai pelaksanaan sistem pemasyarakatan dan Tim Pengamat Pemasyarakatan yang memberi saran mengenai program pembinaan warga binaan pemasyarakatan di setiap Unit Pelaksana Teknis dan berbagai sarana penunjang lainnya.

\section{Tujuan Pembinaan Narapidana}

Perkembangan tujuan pembinaan narapidana, berkaitan erat dengan tujuan pemidanaan. Pembinaan narapidana yang sekarang dilakukan pada awalnya berangkat dari kenyataan bahwa tujuan pemidanaan tidak sesuai lagi dengan perkembangan nilai dan hakikat hidup yang tumbuh di dalam masyarakat. Membiarkan seseorang dipidana, menjalani pidana tanpa memberikan pembinaan, tidak akan merubah narapidana. Bagaimana juga narapidana adalah manusia yang memiliki potensi yang dapat dikembangkan ke arah perkembangan yang positif, yang mampu merubah seseorang untuk menjadi lebih produktif, untuk menjadi lebih baik dari sebelumnya. Potensi itu akan sangat berguna, melalui tangan para pembina narapidana yang mempunyai itikad baik, dedikasi tinggi, semangat tinggi untuk memberikan motivasi bagi perubahan diri narapidana dalam mencapai hari esok yang lebih cerah. $^{8}$

Menurut Sahardjo, tujuan pembinaan adalah untuk pemasyarakatan. Jadi mereka yang menjadi narapidana tidak lagi dibuat jera, tetapi dibina untuk kemudian dimasyarakatkan. Tujuan ini sebagaimana dikutip oleh C.I. Harsono, yang menyebutkan bahwa tujuan pembinaan adalah pemasyarakatan dapat dibagi dalam 3 hal yaitu:

1. Setelah keluar dari lembaga pemasyarakatan tidak lagi melakukan tindak pidana

2. Menjadi manusia yang berguna, berperan aktif dan kreatif dalam membangun bangsa dan negara

3. Mampu mendekatkan diri kepada Tuhan Yang Maha Esa dan mendapatkan kebahagiaan di dunia dan maupun akhirat. ${ }^{9}$

Pembinaan yang dilakukan terhadap seorang narapidana pada dasarnya tidak dapat disamakan dengan pembinaan yang dilakukan terhadap kebanyakan orang pada umumnya.

\footnotetext{
${ }^{7}$ Ibid.

${ }^{8}$ C. I Harsono, Op. Cit, hlm. 43.

${ }^{9}$ Ibid. hlm. 47.
} 
Pembinaan yang dilakukan terhadap seorang narapidana memiliki spesifikasi tertentu dan harus dilakukan dengan menggunakan prinsip-prinsip pembinaan.

Prinsip-prinsip pembinaan narapidana tersebut terdiri atas 4 komponen antara lain

1. Diri sendiri, narapidana itu sendiri

2. Keluarga, adalah anggota keluarga ini, atau keluarga dekat

3. Masyarakat adalah orang-orang yang berada di sekeliling narapidana pada saat masih di luarg lembaga pemasyarakatan/rutan, dapat masyakakat biasa, pemuka masyarakat, atua pejabat setempat.

4. Petugas, dapat berupa petugas kepolisian, pengacara, petugas keagamaan, petugas sosial, petugas lembaga pemasyarakatan, Rutan, Balai pispa, hakim wasmat, dan lain sebagainya. ${ }^{10}$

Keempat komponen pembinaan narapidana harus tahu akan tujuan pembinaan narapidana, perkembangan pembinaan narapidana, kesulitan yang dihadapi dan berbagai program serta pemecahan masalah. Dalam membina narapidana keempat komponen harus bekerjasama dan saling memberikan informasi, terjadi komunikasi timbal balik, sehingga pembinaan narapidana dapat berjalan sesuai dengan yang diharapkan.

Secara ringkas prinsip-prinsip dasar pembinaan narapidana yaitu:

1. Proses pembinaan narapidana harus berangkat dari diri narapidana sendiri. Narapidana sendiri yang harus mau melakukan proses pembinaan bagi diri sendiri, pembinaan bukan muncul dari oang lain.

2. Selain diri narapidana dalam pembinaan narapidana, prinsip dasar kedua yang harus tersentuh untuk ambil bagian secara aktif dalam pembinaan narapidana adalah keluarga. Keluarga harus ikut aktif dalam membina narapidana, karena keluarga adalah orang paling dekat dengan narapidana.

3. Peran serta masyarakat dalam hal ini para pejabat masyarakat tingkat pedesaan, kecamatan, dan para pemuka masyarakat, pemuka agama dimana narapidana tinggal sebelu menjalani pidana diharapkan mampu memberikan pembinaan anggota masyarakat yang menjadi narapidana. Bentuk pembinaan dapat berupa memberikan perhatianb/bantuan keluarga yang anggota keluarganya menjadi narapidana. ${ }^{11}$

\section{Tujuan Pembebasan Bersyarat}

Pembebasan bersyarat atau pelepasan bersyarat atau pelepasan dengan perjanjian merupakan pembebasan terhadap narapidana khususnya yang diberi sanksi pidana penjara yang telah memenuhi persyaratan tertentu sebagaiman diatur dalam Pasal 15 ayat 1 KUHP yang telah diterjemahkan oleh Badan Pembinaan Hukum Nasional (BPHN) Menteri Kehakiman sebagai berikut:

1. Jika terpidana telah menjalani dua pertiga dari lamanya pidana penjara yang dijatuhkan kepadanya yang sekurang-kurangnya harus sembilan bulan, maka ia dapat dikenakan pembebasan bersyarat. Jika terpidana harus menjalani beberapa pidana berturut-turut pidana itu dianggap sebagai satu pidana.

2. Ketika memberikan pelepasan bersyarat ditentukan pula suatu masa percobaan, serta ditetapkan syarat-syarat yang harus dipenuhi selama masa percobaan

${ }^{10}$ Ibid. hlm. 51

${ }^{11}$ Ibid. hlm. 51-57. 
3. Masa percobaan itu lamanya sama dengan sisa waktu pidana penjara yang belum dijalani, ditambah, satu tahun, jika terpidana ada dalam tahanan yang sah, maka waktu itu tidak termasuk masa percobaan. ${ }^{12}$

Dari rumusan Pasal 15 ayat 1 KUHP tersebut menurut P.A. F. Lamintang, bahwa yang dapat dibebaskan secara bersyarat itu hanyalah orang-orang yang oleh hakim telah dijatuhi dengan pidana penjara, yang dua pertiga dari masa pidana mereka itu telah mereka jalankan, dan lamanya dua pertiga dari masa pidana tersebut sekurang-kurangnya adalah sembilan bulan.

Pengertian bebas dari hukuman dengan bersyarat adalah apabila terhadap seseorang yang dijatuhi hukuman panjang dan jika ia telah menjalani hukuman tersebut selama sebagian dari hukuman yang dijatuhkan hakim kepadanya maka ia dapat dibebaskan dari kewajiban untuk menjalani sisa dari hukuman yang seharusnya masih harus dijalani akan tetapi yang disertai atau terikat dengan syarat-syarat. ${ }^{13}$

Pembebasan bersyarat merupakan suatu bentuk pembinaan untuk terpidana di dalam lembaga pemasyarakatan yang diberikan kepada mereka yang telah menjalani pidananya yaitu dua pertiga dari masa hukuman itu atau sekurang-kurangnya sembilan bulan telah dijalani. Narapidana selama menjalani pidananya harus berkelakuan baik serta memenuhi persyaratan lainnya yang telah telah ditetapkan untuk itu. Selama menjalani pembebasan bersyarat narapidana itu diberi masa percobaan yang di dalamnya terdapat perjanjian umum dan perjanjian istimewa. ${ }^{14}$

Maksud dari masa percobaan ${ }^{15}$ tersebut adalah untuk memberikan kesempatan kepada narapidana yang diberikan pembebasan bersyarat agar memperbaiki tingkah laku dan menyadari akan kesalahan-kesalahan yang telah dilakukannya. Dengan demikian narapidana dapat menyesuaikan dirinya dengan kehidupan lingkungan masyarakat yang selanjutnya diharapkan dapat menjadi warga yang baik, berguna dan bertanggung jawab.

Adapun maksud dan tujuan pembebasan bersyarat berdasarkan Pasal 6 Surat Keputusan Menteri Kehakiman Republik Indonesia Nomor M.01-PK.04.10 tahun 1999 tentang Asimilasi, Pembebasan Bersyarat dan Cuti Menjelang Bebas adalah:

1. Maksud dari pembebasan bersyarat adalah sebagai salah satu upaya untuk:

a. Memulihkan hubungan narapidana dengan masyarakat

b. Memperoleh dan meningkatkan peran serta masyarakat secara aktif dalam menyelenggarakan pemasyarakatan.

2. Tujuan pembebasan bersyarat adalah:

a. Membangkitkan motivasi atau mendorong pada diri narapidana kea rah pencapaian tujuan pemasyarakatan

b. Memberikan kesempatan pada narapidana untuk meningkatkan pendidikan dan keterampilan guna mempersiapkan diri sendiri hidup mandiri di tengah masyarakat setelah bebas menjalani pidana

c. Mendorong masyarakat untuk berperan serta secara aktif dalam menyelenggarakan pemasyarakatan. PAF.Lamintang mengatakan bahwa tujuan dari diadakannya pembebasan bersyarat kepada narapidana adalah semata-mata untuk memberikan bantuan dan dukungan kepada narapidana yang selama melaksanakan hukumannya

\footnotetext{
12 P.A.F.Lamintang, Op Cit, hlm. 249.

${ }^{13}$ Ibid. hlm. 247.

${ }^{14}$ Tolib Setiady, 2009, Pokok-Pokok Hukum Penitensier Indonesia, Alfabeta, Bandung, hlm. 131.

15 Unsur-Unsur Percobaan, dalam Pasal 53 yaitu adanya niat, adanya permulaan pelaksanaan dan tidak selesainya pelaksanaan itu bukan semata-mata karena kehendak sendiri, Teguh Prasetyo, 2012, Hukum Pidana, Rajagrafindo Persada, Jakarta, hlm. 153.
} 
berkelakuan baik dan telah melakukan masa hukumannya sebanyak $2 / 3$ dari masa hukuman yang diberikan hakim kepadanya. ${ }^{16}$

\section{Pembinaan dan Pembimbingan Dalam Pembebasan Bersyarat}

Dalam Permenkumham Nomor M.2.Pk. 04-10 Tahun 2007 tentang Syarat dan Tata Cara Pelaksanaan Asimilasi, Pembebasan Bersyarat, Cuti Menjelang Bebas, dan Cuti Bersyarat mengatur mengenai pembinaan dan pembimbingan dalam pembebasan bersyarat yakni:

Pasal 16 menentukan:

1. Pembinaan terhadap narapidana dan anak didik pemasyarakatan yang sedang menjalani asimilasi merupakan tanggung jawaab kepala Lapas atua kepala Rutan.

2. Pembimbingan terhadap narapidana dan anak didik pemasyarakatan yang sedang menjalani pembebasan bersyarat, cuti menjelang bebas atau cuti bersyarat dilaksanakan Oleh Bapas

3. Pembimbingan sebagaimana dimaksud pada ayat 2 dilakukan terhadap perseorangan atau kelompok dan dilaksanakan secara berkala dan berkesinambungan

4. Narapidana dan anak didik pemasyarakatan selama menjalani pembebasan bersyarat, cuit menjelang bebas atau cuti bersyarat tidak diperbolehkan berpergian ke luar negeri, kecuali setelah mendapat izin dari Menteri Hukum dan Hak Asasi Manusia.

Pasal 17 menentukan:

Sebelum asimilasi, pembebasan bersyarat, cuti menjelang bebas atau cuti bersyarat dilaksanakan kepala Lapas atau kepala Rutan, berkewajiban:

1. Memberikan petunjuk agar narapidana atau anak didik pemasyarakatan berprilaku positif di dalam masyarakat dan tidak melanggar persyaratan yang ditetapkan

2. Menandatangani surat menjalani cuti menjelang bebas atau cuti bersyarat berdasarkan keputusan dari Kepala Kantor Wilayah Departemen Hukum dan Hak Asasi Manusia setemapt

3. Menandatangani surat menjalani pembebasan bersyarat berdasarkan keputusan dari Direktur Jenderal Pemasyarakatan

4. Menyerahkan narapidana atau anak didik pemasyarakatan yang menjalani pembebasan bersyarat kepada Kejaksaan Negeri setempat

5. Menyerakan narapidana atau anak didik pemasyarakatan yang menjalani pembebasan bersyarat, cuti menjalang bebas atau cuti bersyarat kepada Bapas dan membuat berita acara penyerahan disertai laporan perkembangan pembinaan dan catatan penting lainnya.

Dalam Permenkumham Nomor M.2.Pk. 04-10 Tahun 2007 tentang Syarat dan Tata cara pelaksanaan asimilasi, pembebasan bersyarat, cuti menjelang bebas dan cuti bersyart mengatur mengenai pengawasan terhadap pembebasan bersyarat yakni:

\section{Pasal 18 menentukan:}

1. Pengawasan terhadap narapidana atau anak pidana yang sedang menjalani pembebasan bersyarat dilakukan oleh Kejaksanaan Negeri dan Bapas

2. Pengawasan terhadap anak negara yang sedang menjalani pembebasan bersyarat dilakukan oleh Bapas.

\section{Pasal 20 menentukan:}

${ }^{16}$ Ibid. hlm 160 
Pengawasan terhadap narapidana atau anak pidana warga negara asing yang diberi pembebasan bersyarat, cuti menjelang bebas, atau cuti bersyarat dilaksanakan oleh pejabat yang berwenang.

\section{Pasal 21 menentukan:}

Kepala Lapas, Kepala Bapas dan Kepala Kantor Wilayah Departemen Hukum dan Hak Asasi Manusia setempat berkewajiban melakukan evaluasi pelaksanaan asimilasi, pembebasan bersyarat, cuti menjelang bebas, atau cuti bersyarat.

\section{Pasal 22 menentukan:}

Kepala Lapas dan Kepala Bapas setiap bulan melaporkan tentang pelaksanaan dan hasil evaluasi asimilasi, pembebasan bersyarat, cuti menjelang bebas atau cuti bersyarat kepada Kepala Kantor Wilayah Departemen Hukum dan Hak Asasi Manusia setempat dengan tembusan kepada Direktur Jenderal Pemasyarakatan.

\section{Pasal 23 menentukan:}

Kepala Kantor Wilayah Departemen Hukum dan Hak Asasi Manusia berkewajiban memelihara data pelaksanaan asimilasi, pembebasan bersyarat, cuti menjelang bebas atau cuti bersyarat, dan melaporkannya bersama-sama dengan hasil evaluasi kepada Direktur Jenderal Pemasyarakatan dengan tembusan kepada Menteri Hukum dan Hak Asasi Manusia.

\section{Pelaksanaan Bimbingan Terhadap Narapidana yang Menjalani Pembebasan Bersyarat}

Pelaksanaan bimbingan terhadap narapidana yang menjalani pembebasan bersyarat didasarkan pada prinsip-prinsip pembinaan dan bimbingan narapidana sebagaimana yang telah dicetuskan oleh Sahardjo. Prinsip-prinsip pembinaan dan bimbingan terhadap narapidana yang menjalani pembebasan bersyarat tersebut sepenuhnya akan dapat tercapai apabila didukung dengan berbagai faktor. Faktor-faktor tersebut merupakan hal mutlak yang tidak dapat terpisahkan dan merupakan unsur penting yang dapat mendukung dalam melaksanakan pembimbingan narapidana tersebut. Adapun yang menjadi faktor penting dalam pembimbingan narapidana tersebut adalah peran serta dari berbagai pihak yang meliputi, diri sendiri yaitu narapidana yang menjalani pembebasan bersyarat itu sendiri, keluarga, adalah anggota keluarga inti, atau keluarga dekat, masyarakat adalah orang orangorang yang berada di sekeliling narapidana pada saat masih di luar lembaga pemasyarakatan/ , dapat masyarakat biasa, pemuka masyarakat atau pejabat setempat, dan petugas dapat berupa petugas kepolisian, pengacara, petugas keagamaan, petugas sosial, petugas lembaga pemasyarakatan, rutan, balai bispa, hakim wasmat, dan lain sebagainya. ${ }^{17}$

Pelaksanaan pembimbingan terhadap narapidana yang mendapat pembebasan bersyarat kepada Bapas wajib mengadakan perencanaan, pelaksanaan, dan pengendalian atas kegiatan program pembimbingan. ${ }^{18}$ Kegiatan pembimbingan tersebut diarahkan pada kemampuan klien untuk berintegrasi secara sehat dengan masyarakat. pembimbingan klien tersebut dilaksanakan melalui 3 (tiga) tahapan yaitu tahap awal, tahap lanjutan, dan tahap terakhir. ${ }^{19}$

\footnotetext{
${ }^{17}$ Tolib Setiady, Op. Cit, hlm. 138-140

18 Dalam Keputusan Menteri Kehakiman RI Nomor :M.01-PR.07.03. Tahun 1987 tanggal 2 Mei 1987 tentang Organisasi dan Tata Kerja Balai Pemasyarakatan tugas pokok dan fungsi Balai Pemasyarakatan, yaitu memberikan bimbingan dan pengawasan terhadap klien pemasyarakatan . bimbingan klien pemasyarakatan adalah bagian dari sistem pemasyarakatan yang menjiwai tata peradilan pidana dan mengandung aspek penegakan hukum dalam rangka pencegahan kejahatan dan bimbingan pelanggar hukum, dalam pelaksanaannya sesuai dengan peraturan perundang-undangan yang berlaku, Eva Achjani Zulfa, Anugrah Rizki Akbari, dan Zakky Ikhsan Samad, 2017, Perkembangan Sistem Pembinaan dan Sistem Pemasyarakatan, Raja Grafindo Persada, Jakarta, hlm. 91

${ }^{19}$ Djisman Samosir, 2016, Penologi dan Pemasyarakatan, Nuansa Aulia, Bandung, hlm.245
} 
Pembimbingan tahap awal meliputi penerimaan dan pendaftaran klien, pembuatan penelitian kemasyarakatan untuk bahan pertimbangan, penyusunan program pembimbingan, pelaksanaan program pembimbingan, dan pengendalian pelaksanaan program pembimbingan tahap awal,

Pembimbingan tahap lanjutan meliputi penyusunan program pembimbingan tahap lanjutan, pelaksanaan program pembimbingan, dan pengendalian pelaksanaan program pembimbingan tahap lanjutan.

Pembimbingan tahap akhir meliputi, penyusunan program pembimbingan tahap akhir, pelaksaan program pembimbingan tahap akhir, pengendalian pelaksanaan program pembimbingan, penyiapan klien untuk menghadapi tahap akhir pembimbingan dengan mempertimbangkan pemberian pelayanan bimbingan tambahan dan pengakhiran tahap pembimbingan, klien dengan memberikan surat keterangan akhir pembimbingan oleh kepala Bapas.

Pembimbingan tahap awal dimulai sejak yang bersangkutan berstatus klien sampai dengan $1 / 4$ masa pembimbingan. pembimbingan tahap lanjutan dilaksanakan sejak berakhir pembimbingan tahap awal sampai degnan $3 / 4$ masa pembimbingan. Pembimbingan tahap akhir dilaksanakan sejak berakhirnya tahap pembimbingan lanjutan sampai dengan berakhirnya masa pembimbingan.

Teknis pelaksanaan bimbingan terhadap narapidana yang mendapat izin pembebasan bersyarat adalah:

a. Pelaksanaan pembebasan bersyarat narapidana adalah jaksa pada kejaksaaan negeri di wilayah hukum lembaga pemasyarakatan tempat narapidana yang bersangkutan menjalani pidana.

b. Apabila narapidana menjalankan masa pembebasan bersyarat bukan di wilayah hukum jaksa yang melaksanakan maka dalam jangka waktu 7 hari setelah tanggal pelaksanaan narapidana tersebut harus melapor ke kejaksaaa negeri di tempat menjalani masa pembebasan bersyaratnya sebagaimana ditunjuk dalam keputusan pembebasan bersyarat dengan memperlihatkan buku bebas besyarat yang diterimanya dan diantar oleh petugas balai bimbingan kemasayarakatan.

c. Narapidana yang akan melaksanakan pembebasan bersyarat diserah terimakan oleh kepala lembaga pemasyarakatan kepada Balai Bimbingan Kemasyarakatan yang akan memberikan bimbingan yang disertai risalah singkat pembinaannya selama dalam lembaga pemasyarakatan.

d. Bimbingan terhadap narapidana dilaksanakan oleh Balai bimbingan kemasyarakatan melalui program bimbingan dengan memperhatikan pertimbagan Tim Pengamat Pemasyarakatan (TPP) balai bimbingan kemasyarakatan. ${ }^{20}$

Berdasarkan hasil evaluasi dan ternyata klien tidak mempergunakan kesempatan yang diberikan dengan baik, maka izin pembebasan bersyarat dapat dicabut apabila narapidana (klien) yang bersangkutan:

a. Hidup secara tidak teratur, suka membuat onar, mabuk-mabukan, bermain judi, mengunjungi tempat mesum, mengganggu ketentraman umum atau masyarakat.

b. Malas bekerja,

c. Bergaul dengan residivis

d. Mengulangi tindak pidana.

e. Menimbulkan keresahan dalam masyarakat

f. Melanggar tata tertib.

${ }^{20}$ P.A.F Lamintang dan Theo Lamintang, 2012, Hukum Penitensier Indonesia, Sinar Grafika, Jakarta, hlm. 147 
Narapidana yang dicabut izin pembebasan bersyaratnya dikenakan sanksi:

a. Kembali mengikuti pendidikan dalam lembaga pemasyarakatan sesuai dengan peraturan yang berlaku

b. Hukuman disiplin menurut peraturan perundang-undangan yang berlaku

c. Pada tahun pertama setelah pencabutan kut, untuk sementara watku tidak diberikan remisi.

Selama masa menjalani masa pembebasan bersyarat di luar lembaga pemasyarakatan tidak dihitung sebagai menjalani pidana. Selama menjalani sisa pidananya tidak diperkenankan lagi memperoleh izin pembebasan bersyarat. Dalam pembimbingan narapidana harus diciptakan situasi dan suasana yang dapat membuat narapidana dapat larut dan menerima pembinaan dan bimbingan dengan sempurna. Beberapa metode pembinaan dan bimbingan yang dapat digunakan pembimbing kemasyarakatan sebagai pedoman dalam pembimbingan narapidana yang mendapat pembebasan bersyarat adalah:

a. Metode pembimbingan berdasarkan situasi

b. Pembimbingan perorangan

c. Pembimbingan secara kelompok

d. Belajar dari pengalaman

e. Auto sugesti.

\section{Ad.a. Metode Pembimbingan Berdasarkan Situasi}

Dalam kehidupan sehari-hari dapat dijumpai para narapidana atau orang biasa atau awam akan mempunyai kecenderungan untuk terpengaruh oleh situasi baikitu situasi sosial, alam, kejiwaan, atau yang lainnya. Dalam pembimbingan berdasarkan situasi setiap pembimbing harus mampu merubah cara berpikir narapidana untuk tidak tergantung kepada situasi yang menyertai tetapi menguasai situasi tersebut sehingga pembinaan dapat diterima dengan baik, lengkap dan dapat dihpahami secara sempurna. Merubah dari tergantung kepada situasi menjadi menguasai situasi dapat terjadi jika narapidana telah mengenal dirinya. Dengan menguasai situasi pembinaan dapat diberikan dua pendekatan dalam pembinaan, menurut kebutuhan pembinaan bagi narapidana yaitu pendekatan dari atas (top approach) dan pendekatan dari bawah (bototom approach).

\section{Ad. b. Pembinaan Perorangan}

Pembinaan perorangan ini diberikan kepada narapidana secara perorangan oleh petugas Pembina. Pembina perorangan tidak harus terpisah-pisah tetapi dapat dibina dalam kelompok bersama dan pengamanannya secara sendiri-sendiri. Hal ini dapat diketahui karena tingkat kematangan intelektual, emosi, logika dari tiap-tiap narapidana tidaklah sama. Ketidaksamaan inilah menuntut agar diterapkannya pembinaan secara perorangan. Pembinaan secara perorangan akan banyak manfaat jika narapidana mempunyai kemauan untuk merubah dirinya sendiri, tetapi pembinaan ini tidak atau kurang diperhatikan oleh para pembina. Para Pembina lebih suka mengadakan pembinaan secara kelompok karena pembinaan secara kelompk lebih mudah penyampaiannya pada hal dari segi keefektifannya dan keefisiensinya pembinaan secara perorangan akan lebih mengena.

Perhatian dalam pembinaan akan membawa banyak perubahan dalam diri narapidana sehingga akan sangat berpengaruh dalam merealisasi perubahah diri sendiri. Pembinaan secara perorangan akan lebih banyak bermanfaat jika narapidana juga mempunyai kemampuan untuk merubah dirinya sendiri. Tanpa kemauan untuk merubah diri sendiri akan sulit untuk dicapai hasil pembinaan yang maksimal sekalipun kemauan untuk merubah diri sendiri dapat timbul stelah pembinaan secara perorangan dalam hal ini akan membantu narapidana dalam melakukan perubahan bagi diri sendiri. 


\section{Ad. c. Pembimbingan Secara Kelompok}

Pembimbingan secara kelompk dapat baik menurut kebutuhan pembinaan yang ditentukan oleh pihak pembimbing sesuai dengan kebutuhan yang dirasakan oleh narapidana. Pembimbingan berkelompok ini dilakukan dengan metode ceramah, Tanya jawab, simulasi, permainan, peran atau pada materi yang akan disajikan tujuan yang hendak dicapai dari proses pembinaan. Dalam pembinaan secara kelompok ini, peran kelompok harus tetap dilibatkan baik secara individu maupun secara kelompok jadi bukan hanya Pembina saja yang aktif melainkan yang dibina pun harus aktif.

Dalam pembinaan secara kelompok para pembimbing harus mampu mengajak narapidana untuk memahami nilai-nilai positif yang tumbuh di masyarakat atau kelompok tersebut untuk dijadikan bahan pembinaan, karena setelah keluar dari lembaga pemasyarakatan narapidana akan berbaur kembali dengan masyarakat atau kelompok keluarga, sehingga nilai positif yang tumbuh dalam keluarga, masyarakat, dan kelompok akan sangat berguna sekali bagi pemahaman masyarakat yaitu hidup saling ketergantungan.

\section{Ad.d. Belajar dari Pengalaman.}

Pembinaan dilakukan berdasarkan pengalaman narapidana sendiri, sering didengar bahwa pengalaman adalah guru terbaik tetapi ada kalanya pengalaman tersebut datangnya terlambat. Dalam belajar dari pengalaman adalah belajar mengenai komunikasi dan pengalaman baru baik pengalaman diri sendiri atau pengalaman narapidana lainnya. Komunikasi penting karena banyak hal terjadi karena kesalahan komunikasi.

Komunikasi adalah awal dari segala tindakan, komunikasi merupakan mata rantai dari segala tindakan manusia. Dengan memahami komunikasi akan menekan kesalahan sekecil mungkin. Bila ingin mencapai suatu keberhasilan maka komunikasi harus dikuasi. Dipahami, sebagai bagian yang tidak terpisah untuk mencapai tujuan.

\section{Ad. e. Auto Sugesti}

Pembinaan ini dilakukan dalam kehidupan semua manusia timbul mulai dari pendidikan, agama dan sebagainya. Ini merupakan sarana atau alat untuk mempengaruhi alam sadar manusia dengan cara memasukkan saran-saran atau pengaruh atau perintah untuk melakukan suatu tindakan yagn timbul dari dan untuk diri sendiri melalui alam sadar untuk mempengaruhi alam bawah sadar. Auto Sugesti adalah sarana atau alat untuk mempengaruhi bawah sadar manusia dengan cara memasukkan saran-saran atau pengaruh atau perintah untuk melakukan suatu tindakan sesuai dengan sarana yang diberikan.

Metode auto sugesti bagi narapidana dapat dilakukan dengan memberikan saran, pengaruh, perintah kepada diri narapidana, sesuatu yang positif bagi perubahan hidupnya. Saran harus dilakukan dengan penuh perasaan, emosi yang dalam sehingga akan mempengaruhi pikian bawah sadar.

Tujuan dilakukannya pembimbingan tersebut agar narapidana tidak mengulangi perbuatannya yang merugikan masyarakat. pembimbingan ini dilakukan dengan cara:

1. Memanggil klien untuk datang ke bapas, disini klien diberi nasehat dan kegiatan sesuai denagn kemampuan. Jika perlu dipanggi juga orang-orang yang mmpunyai keterkaitan dalam pembimbingan klien tersebut.

2. Pembimbing kemasyarakatan meakukan kunjungan di tempat tinggal atua tempat kerja narapidana, Pembimbing kemasyarakatan juga memperhatikan keadaan rumah tangga, kehidupan dan lingkungan narapidana.

3. Mengadakan komunikasi dengan klien, misalnya menelepon, menulis sesuatu dalam majalah untuk klien atau kirim sala melalui seseorang dan sebagainy. 
4. Menyuruh klien melakukan sesuatu misalnya menyuruh klien melihat temannya yang sakit, ikut dalam kerja bakti dan sebagainya.

5. Mengajak klien berrekreasi

Pengertian kemasyarakatan di sini adalah segala sesuatu yang menyangkut sifat hubungan antara manusia yang satu degan yang lainnya dan antara manusia yang satu degnan yang lainnya dan antara manusia dengan masyarakat sekitarnya. Dalam pelaksanannya tugasnya peranan bapas merupakan perwujudan daripada reklasering. Namun tugas-tugas bapas itu bukannya hanya saja masalah-masalah tetapi melipuit orang dewasa maupun sudah cukup umur. Kesemuanya bertujuan untuk membantu terpidana selama menjalani pembebasan bersyarat, dengan memberikan bimbingan agar narapidana tersebut menginsyafi atas perbuatan bimbingan agar narapidana tersebut menginsyafi atas perbuatan yang telah dilakukannya yang berakibat merugikan pihak lain meaupun diri sendiri.

\section{KESIMPULAN}

Pembinaan terhadap warga binaan yang menjalani pembebasan bersyarat dilaksanakan berdasarkan sistem pemasyarakatan. Pelaksanaan bimbingan terhadap warga binaan pemasyarakatan yang mendapat pembebasan bersyarat sifatnya adalah melanjutkan pembinaan yang telah dilakukan oleh pihak lembaga pemasyarakatan atau memantapkan program pembinaan yang diberikan pada saat narapidana masih berada di lembaga pemasyarakatan. Pelaksanaan bimbingan ditempuh melalui dua cara yaitu mewajibkan narapidana untuk datang ke Bapas atau pembimbing kemasyarakatan melakukan kunjungan di tempat tinggal atau tempat kerja narapidana. Pelaksanaan bimbingan terhadap narapidana yang menjalani pembebasan bersyarat tersebut tidak lepas dari peran pihak-pihak tertentu yang saling mendukung baik dengan adanya peran dari narapidana itu sendiri, peran keluarga, maupun peran masyarakat. Maka untuk memaksimalkan bimbingan terhadap narapidana tersebut harus ada hubungan yang saling mendukung antara pihak-pihak tersebut, dan jika keadaan tersebut terjalin maka dapat dipastikan pelaksanaan bimbingan yang diberikan terhadap narapidana yang menjalani pembebasan bersyarat tersebut dapat tercapai.

\section{DAFTAR PUSTAKA}

Djisman Samosir, 2016, Penologi dan Pemasyarakatan, Nuansa Aulia, Bandung

Dwidja Priyatno, 2006, Sistem Pelaksanaan PIdana Penjara di Indonesia, Refika Aditama, Bandung

Eva Achjani Zulfa, Anugrah Rizki Akbari, dan Zakky Ikhsan Samad, 2017, Perkembangan Sistem Pembinaan dan Sistem Pemasyarakatan, Raja Grafindo Persada, Jakarta

Marlina, 2012, Hukum Penitensier, Refika Aditama, Bandung

P.A.F Lamintang dan Theo Lamintang, 2012, Hukum Penitensier Indonesia, Sinar Grafika, Jakarta

P.A.F. Lamintang, 1998, Hukum Penitensier Indonesia, Cetakan Ketiga, Armico, Bandung

Petrus Irwan Panjaitan, dan Pandapotan Simorangkir, 2005, Lembaga Pemasyarakatan dalam Perspektif Sistem Peradilan Pidana, Pustaka Sinar Harapan, Jakarta

Sudarsono,1999, Kamus Hukum, Cetakan II, Rineka Cipta, Jakarta

Sahardjo, Pohon Beringin Pengayom Hukum Pancasila, Pidato Pengukuhan pada tanggal 3 Juli 1963, di Istana Negara, Universitas Indonesia

Teguh Prasetyo, 2012, Hukum Pidana, Rajagrafindo Persada, Jakarta

Tolib Setiady, 2009, Pokok-Pokok Hukum Penitensier Indonesia, Alfabeta, Bandung

Republik Indonesia, Undang-Undang Nomor 12 Tahun 1995 tentang Pemasyarakatan 
, Peraturan Pemerintah RI Nomor 32 Tahun 1999 tentang Syarat dan Tata Cara Pelaksanaan Hak Warga Binaan Pemasyarakatan , Peraturan Pemerintah RI Nomor 31 Tahun 1999 tentang Pembinaan dan Pembimbingan Warga Binaan Pemasyarakatan. 